\title{
Performance of glue laminated timber beams composed of sengon wood (Albizia falcatara) and coconut wood (Cocos nucifera) with nylon- threads reinforcement
}

\author{
Kusnindar ${ }^{1,2, *}$, Sri Murni Dewi ${ }^{3}$, Agoes Soehardjono ${ }^{3}$, and Wisnumurti $^{3}$ \\ ${ }^{1}$ Doctoral student in Civil Engineering Department of Brawijaya University, Indonesia \\ ${ }^{2}$ Lecturer of Civil Engineering Department of Tadulako University, Indonesia \\ ${ }^{3}$ Lecturer of Civil Engineering Department of Brawijaya University, Indonesia
}

\begin{abstract}
This paper aims to describe the performance of mix-glue laminated timber beams that are given a nylon strapping as external reinforcement with the three-point bending test to three groups of beams based on the span-to-depth ratio, i.e.: G11, G8, and G5 groups. Each group consists of three types of lamination compositions, namely: Type I, whole lamination consists of sengon wood; Type II, the placement of the coconut wood lamination as the outermost; Type III, similar to type II with added nylon straps with a distance of $5 \mathrm{~mm}$. The bending test results show differences in elastic modulus, flexural strength and shear strength of the glue-laminated timber beams. Based on the comparison of glulam beams consisting of six laminations of sengon wood it was found that the placement of the coconut wood as the outermost lamination succeeded in increasing the elastic modulus, the flexural and shear strength of beams by $28 \%, 13 \%$, and $34 \%$, respectively. In addition, the reinforcement with nylon straps results in the modulus of elasticity, bending and shear strength of glulam to increase by by $41 \%, 2 \%$, and $49 \%$ respectively.
\end{abstract}

\section{Introductions}

Sengon wood (Albizia falcatara) is a low-grade timber with a density of only 0.29-0.314 gr $/ \mathrm{cm}^{3}$ at $12-15 \%$ moisture content [5]. The low density of timber provides advantages in the heaviness of building structures. On the other hand, coconut wood (Cocos nucifera) has better mechanical properties and has a density of $0.64-0.96 \mathrm{gr} / \mathrm{cm}^{3}$ [1]. As a result of plantations, these two timber species have the potential for adequate availability $[3,6]$. Unfortunately, the utilization of these two types of wood for structural components of buildings, especially in Indonesia, is still minimal. This is because of the low mechanical characteristics of sengon wood and the varying grades of coconut wood density.

Improvement of the performance of low-grade timber can be done through the implementation of mix-glue laminated timber system (mix-glulam). The mix-glulam timber consists of two or more species of wood with different strength grades and is bonded with adhesion. The high-grade timber was placed as the outermost lamination and the low-grade

* Corresponding author: kus_untad@yahoo.co.id 
as a core lamination. As an example, the mix of poplar and eucalyptus can produce an elasticity $51 \%$ higher than the modulus of elasticity of poplar individually. Likewise, the bending strength increased by $35 \%$ when compared to poplar solid beams [4]. In addition, performance improvement of timber beams can also be produced by an external reinforcement. The strengthening generally applied the addition of non-wood materials such as glass fiber, FRP, GFRP and steel plate on the timber beam. These materials have a much higher strength than timber. Some studies suggest that strengthening using ingredients can increase the bending strength and stiffness of timber beams significantly. Strengthening of tension zone of timber beams by steel plates resulted in increased bending strength by $41 \%$ and stiffness by $20 \%$ [8]. The application of glass fiber-reinforced polymer (GFRP) on the side of the timber beams along the shear span has resulted in an increase in shear strength by $40 \%$ [7].

Therefore, this study aims to describe the performance of glulam mixed beams consisting of coconut wood on outermost laminations and sengon wood on core laminations. This will also explain the effect of nylon-strapped applications as external reinforcement on beam performance. The development of this mix-glulam system is expected to expand the scope of utilization of sengon wood and coconut wood while reducing the dependence of the timber supply from forests.

\section{Experimental programs}

\subsection{Specimen preparation}

The lamina materials to be used are sengon wood and coconut wood obtained from the sawmill industry in Malang, East Java. Before use, the laminae are dried for about three months. This drying is done naturally in an open-topped location until the water content is about $12-16 \%$. Then, density examination and material sorting were conducted in accordance with the local control set. The density of the sengon and coconut wood used was $0.32-0.34 \mathrm{gr} / \mathrm{cm}^{3}$ and $0.58-0.85 \mathrm{gr} / \mathrm{cm}^{3}$ respectively. The materials of lamination that had a density outside the determined value were then set aside and not used.

After the lamina has been determined to be used to make glulam-beams, the lamina surface is then flattened using a planer machine. This process is intended to obtain a uniform lamina dimension of $2.5 \mathrm{~cm}$ in thickness, $6 \mathrm{~cm}$ in width and $200 \mathrm{~cm}$ in length. This process will simultaneously clean the surface of any lamina from the dirt that might inhibit the gluing process. So, the laminae were grouped based on the composition plan as shown in Figure 1.

Furthermore, the glulam beams are divided into three groups based on the span to height ratio i.e.: group $\mathrm{G} 11(\mathrm{~L} / \mathrm{h}=11.2)$, group $\mathrm{G} 8(\mathrm{~L} / \mathrm{h}=8.8)$ and group $\mathrm{G} 5(\mathrm{~L} / \mathrm{h}=5.2)$. Each group consisted of three types of beams according to the lamina configuration: type (I) beam consisted of six laminations of sengon wood; type (II) beam consisted of four laminations of sengon wood in the core zone and one lamination of coconut timber in each of the top and bottom; type (III) beam was similar to type (II) but it got external reinforced nylon straps. Every type consisted of three beams, so the total glulam beams were 27 .

After all, laminations were ordered and grouped based on their types, then the adhesive of two sides was spread. As an adhesive, a mixture of urea-formaldehyde-resin powder (UF) and water is used. For the adhesive composition, two parts of UF powder and one part of water is used. In this case, the gluing is done with a glue spread rate of $350 \mathrm{~g} / \mathrm{m}^{2}$. The glue spread process was done for a maximum of 15 minutes for every beam. Then, it was followed by putting horizontal and vertical clamps with spaces of $25 \mathrm{~cm}$ along the beams. 


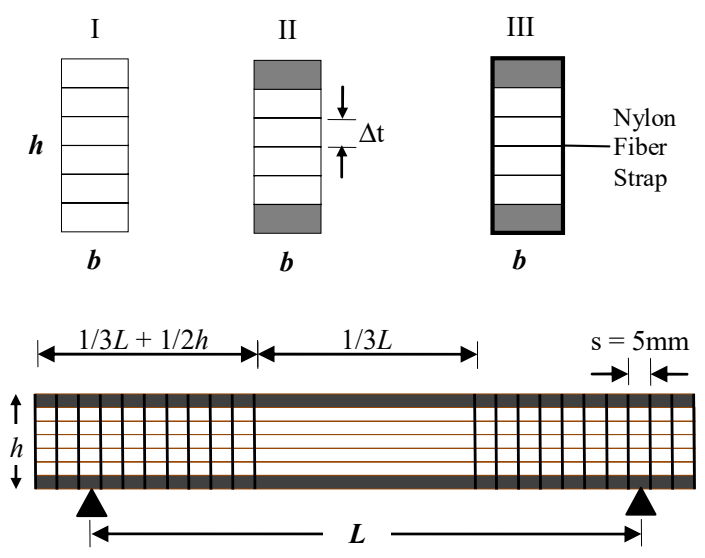

$$
\begin{array}{ccc}
\text { Group of beams: } & \\
\text { G11 } & (\mathrm{L}=1740 & \mathrm{mm}) \\
\text { G8 } & (\mathrm{L}=1360 & \mathrm{mm}) \\
\text { G5 } & (\mathrm{L}=810 & \mathrm{mm})
\end{array}
$$

Type of beams: I, II, and III

Cross section of beams:

$b=55 \mathrm{~mm}$

$h=155 \mathrm{~mm}$

$\Delta_{\mathrm{t}}=26 \mathrm{~mm}$

Space of $\operatorname{strapp}(\mathrm{s})=5 \mathrm{~mm}$

$\square$ Coconut Timber

Albazia falcataria

Fig. 1. Glulam beam geometry and cross section.

For next step, a cold pressure was done by applying a pressure force of $2.0 \mathrm{MPa}$. This was done by using a hydraulic jack at the point where the clamp was attached. In this step, the horizontal clamp was released immediately at the moment the pressure started working. After the process of pressure was done, it was then followed by adhesion maturation. This was done by putting the beam with an attached clamp on a flat surface for about18 hours.

When the gluing was perfectly done, then vertical clamp was released. Leveling with a planner to achieve a width of $55 \mathrm{~mm}$ was done when all beams in all groups were completely glued. The top and bottom side of the beam were not planed because the intended beam depth was achieved. The final stage was the application of nylon straps to every beam from the type III group. The nylon used was in the form of $1.0 \mathrm{~mm}$ diameter threads. The application was done by wrapping the nylon fiber manually. The stages above are applied to each laminated beams as schematically shown in Figure 2.
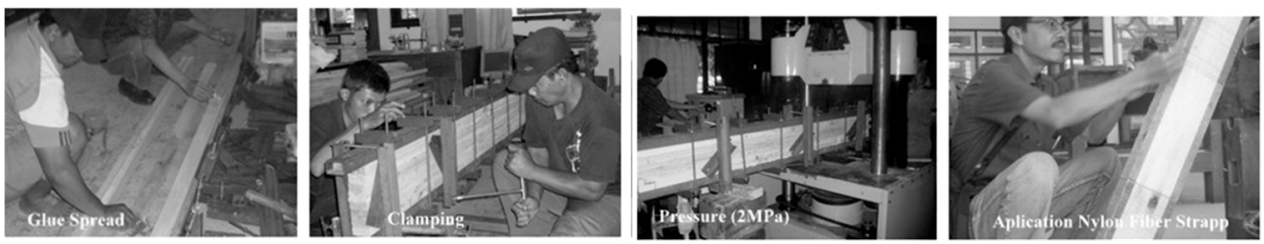

Fig. 2. Glulam beams manufacture.

\subsection{Static three-point bending test}

The static three-point bending test of glulam beams is intended to obtain data on the load-deflection of each glue laminated beam. The test was carried out according to ASTM D198-02 [2]. The instrument configuration of the static three-point bending test beams is presented in Figure 3. 


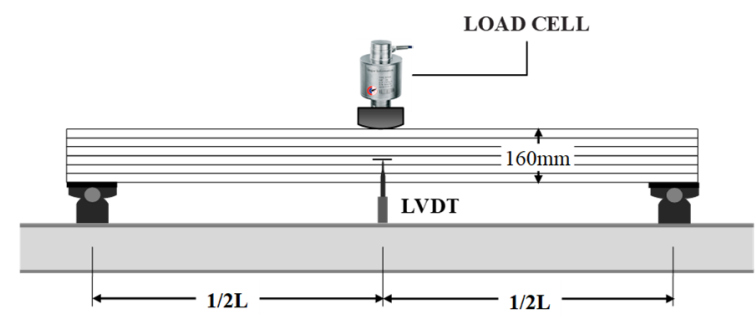

Fig. 3. Set-up of three-point bending test.

\section{Experiment results}

\subsection{Mechanical properties of glulam beams}

Average value of mechanical properties of glulam beams is presented in Table 1 .

Table 1. Summary data result of three-point load bending test of glulam.

\begin{tabular}{|c|c|c|c|c|c|c|c|}
\hline Beams Series & $\begin{array}{c}\boldsymbol{h} \\
(\mathrm{mm}) \\
\end{array}$ & $\begin{array}{c}B \\
(\mathrm{~mm}) \\
\end{array}$ & $\begin{array}{c} \\
(\mathrm{mm}) \\
\end{array}$ & $L / h$ & $\begin{array}{c}\sigma_{\max } \\
(\mathrm{MPa})\end{array}$ & $\begin{array}{c}E \\
(\mathrm{MPa})\end{array}$ & $\begin{array}{c}\delta_{\max } \\
(\mathrm{mm})\end{array}$ \\
\hline G11.I & \multirow{3}{*}{155} & \multirow{3}{*}{55} & \multirow{3}{*}{1,740} & \multirow{3}{*}{11.2} & 38.9 & 5,070 & 32.8 \\
\hline G11.II & & & & & 41.3 & 5,889 & 27.2 \\
\hline G11.III & & & & & 38.1 & 6,077 & 20.5 \\
\hline G8.I & \multirow{3}{*}{155} & \multirow{3}{*}{55} & \multirow{3}{*}{1,360} & \multirow{3}{*}{8.8} & 55.6 & 4,533 & 15.9 \\
\hline G8.II & & & & & 49.8 & 4,934 & 14.4 \\
\hline G8.III & & & & & 53.3 & 4,654 & 16.2 \\
\hline G5.I & \multirow{3}{*}{155} & \multirow{3}{*}{55} & \multirow{3}{*}{810} & \multirow{3}{*}{5.2} & 51.3 & 2,947 & 7.6 \\
\hline G5.II & & & & & 65.4 & 2,377 & 7.6 \\
\hline G5.III & & & & & 72.4 & 2,333 & 8.9 \\
\hline
\end{tabular}

\subsection{Load-displacement curve}

\subsubsection{Glulam beams group G11}

The load-deflection curve of the G11 group is presented in Figure 4. All beams went through a linear and nonlinear phase before reaching failure. The nonlinear phase of the type I-beams was longer than that of type II and III. Additionally, the type I-beams fail at a lower load. 

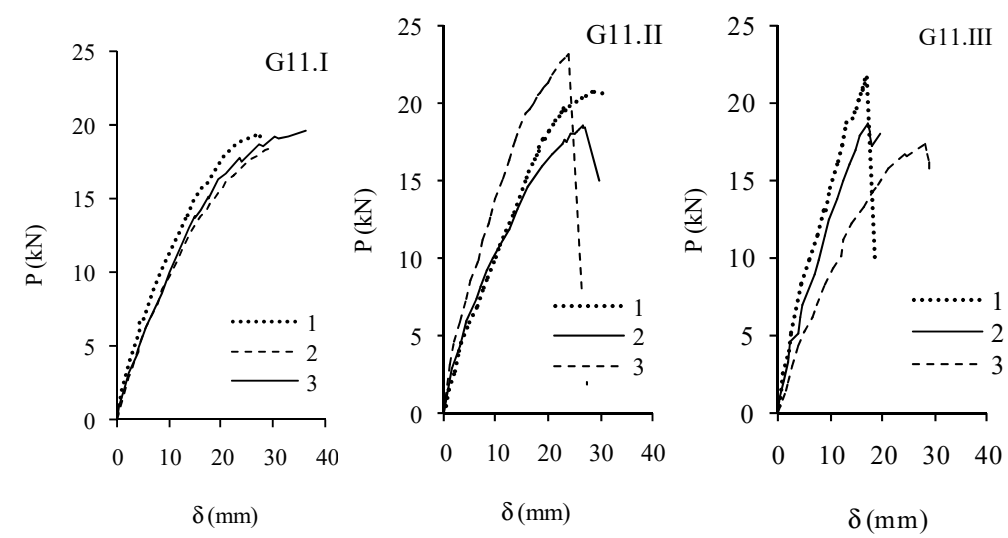

Fig. 4. Load-deflection curve for glulam group G11.

\subsubsection{Glulam beams group G8}

The load-deflection curve of the glulam beam group G8 is presented in Figure 5. There is no significant difference in behavior between the types of beams. The linear phase is more dominant for all of them have until reaching failure.
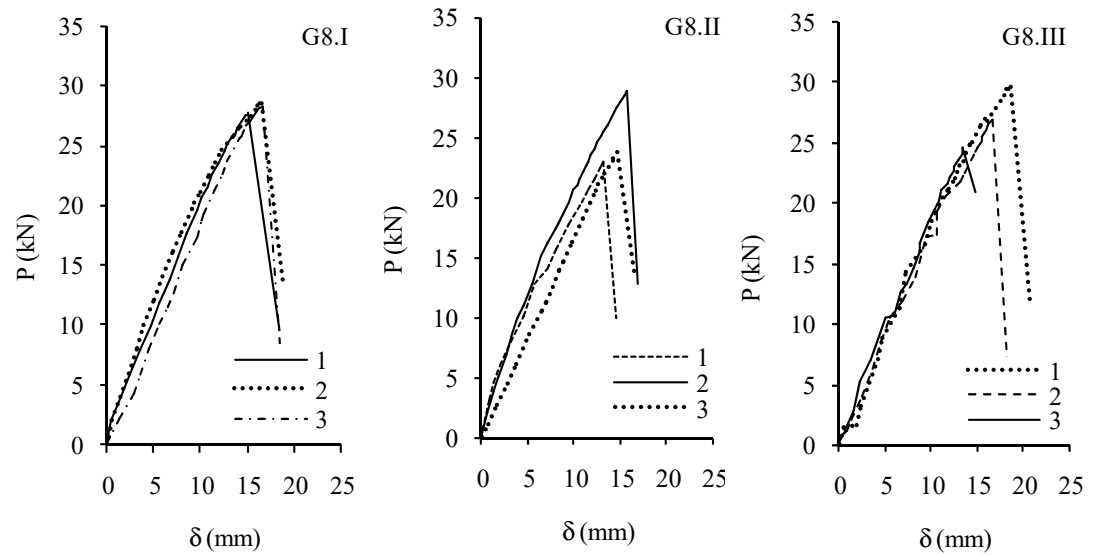

Fig. 5. Load-deflection curve for glulam group G8.

\subsubsection{Glulam beams group G5}

The load-deflection curve of the glulam beam group G5 is presented in Figure 6. There are differences in the pattern of the curve between the three types of glulam beams. The loaddeflection curve of the type I-beams show a clear difference between the linear and nonlinear phase, but not so for type I and III. Beams of type II and III did not show a nonlinear phase up till failure was reached. There was a significant increase in the maximum load when compared with type I of glulam. 

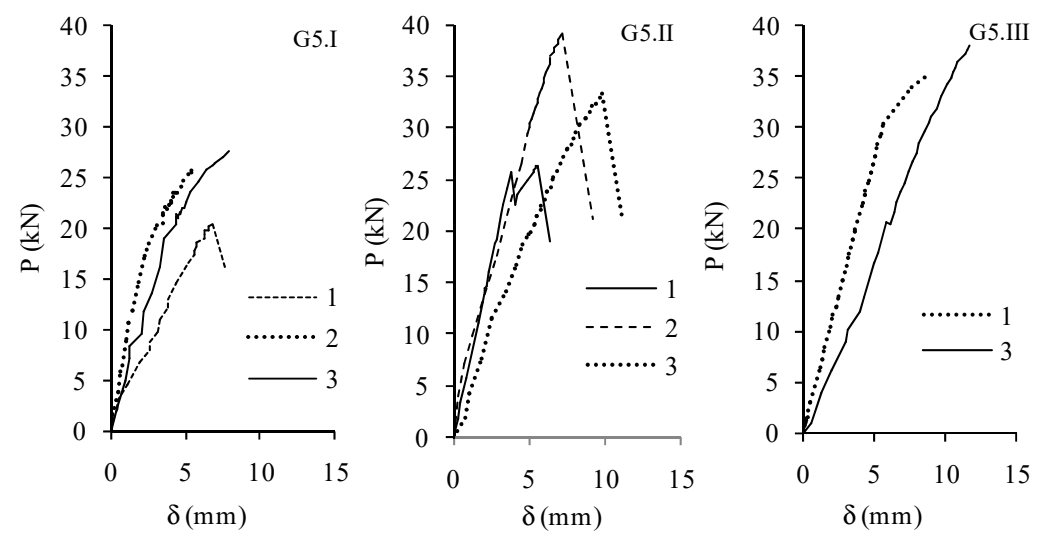

Fig. 6. Load-deflection curve for glulam group G5.

\section{Discussion}

\subsection{Effect of formation of laminations and reinforcement to the modulus of elasticity}

Placement of coconut timber as the outer zone of glue-laminated timber beams and strengthening with nylon fiber straps produced a significant increase in modulus of elasticity for the beams. Figure 7 shows that the placement of coconut timber lamination increases the modulus of elasticity by $28 \%$. The strengthening with the nylon strap increased the modulus of elasticity by $41 \%$.

The comparison between laminated beam types II and III obtainedthe fact that the nylon fibers straps improve the modulus of elasticity of the beams by $13 \%$. So the modulus of elasticity of glue-laminated timber beams is significantly affected by the composition of the laminae. This suggests that the strength increase of the outer zone lamination will increase the strength of the laminated beams as stated by [10].

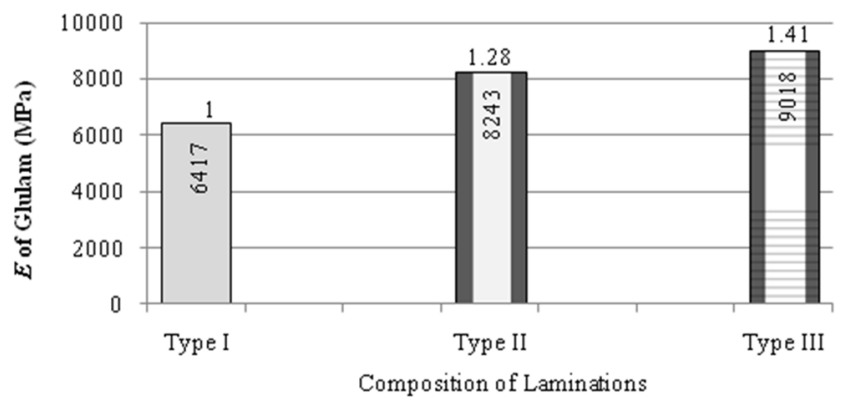

Fig. 7. Modulus of elasticity of glulam beams; over the bars, the increase in the percentage of the modulus of elasticity due to the placement coconut timber and nylon fiber strengthening.

However, when referring to the apparent modulus of elasticity as shown in Table 1, the changes that occur in addition due to being affected by the configuration of the lamination, are also influenced by the span-to-depth ratio of the glulam beam, in line with [9]. If the $\mathrm{L} / \mathrm{h}$ value is getting smaller, it would also reduce the value of the modulus of elasticity. Thus, the decrease of the $\mathrm{L} / \mathrm{h}$ value produces an increase of shear strength of the beam. 


\subsection{Effect of formation of laminations and strengthening to bending and shear strength}

Based on Figure 8 the fact that the bending strength of glue-laminated timber beams is influenced by the configuration of the lamina can be seen. In the G11 group, the placement of coconut timber as the outer lamina and nylon fiber strengthening only provides an improved bending strength by $13 \%$ and $2 \%$ respectively.

On the other hand, the placement of the coconut wood laminations and the reinforcement with nylon strapping produce a fairly high shear strength. In this case, the laminate formations II and III respectively produce a maximum shear stress of $34 \%$ and $49 \%$, higher than formation I.

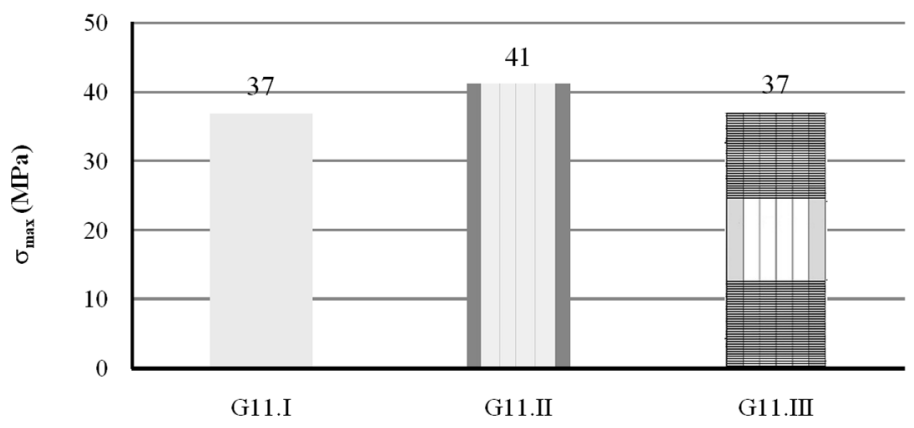

Formation of laminations

Fig. 8. Bending strength of glulam beams.

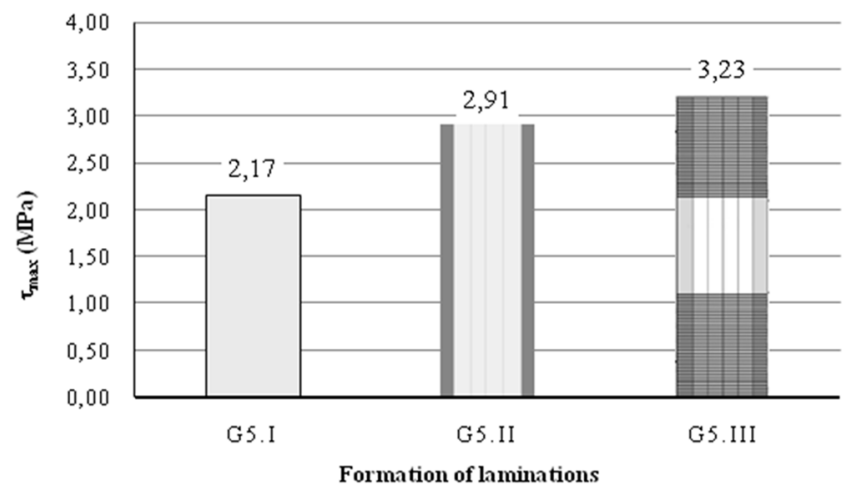

Fig. 9. Shear strength of glulam beams.

\subsection{Failure mode of glulam beams}

The changes of the failure mode of glulam beams due to the composite action of sengoncoconut timber and nylon fiber reinforcement is presented in Figure 10 and 11. The effect of the placement of coconut timber as the outer lamina in glue-laminated timber beams with $\mathrm{L} / \mathrm{h}=11.2$ is the reversal of the failure mode, from the compression failure to the tension failure. On the other hand, the beams reinforced with nylon fiber straps has contributed to a reduction in the damage intensity of the beams in failure. In this case, the failure mode of beam-type II and III are more brittle than that of type I. 

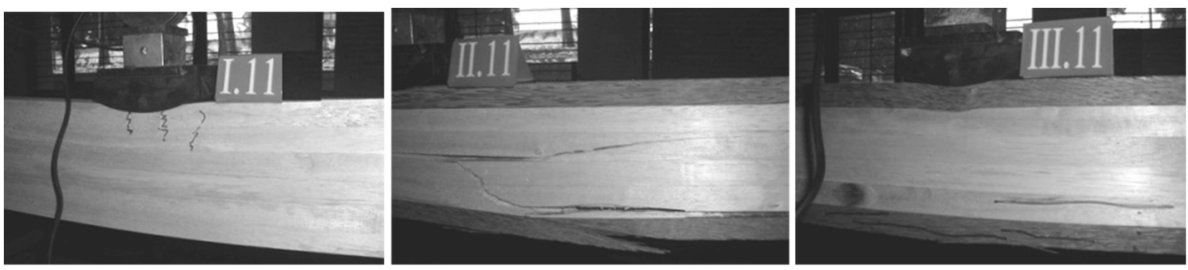

Fig. 10. Typical failure of glulam beams G11 Type I, II, III.
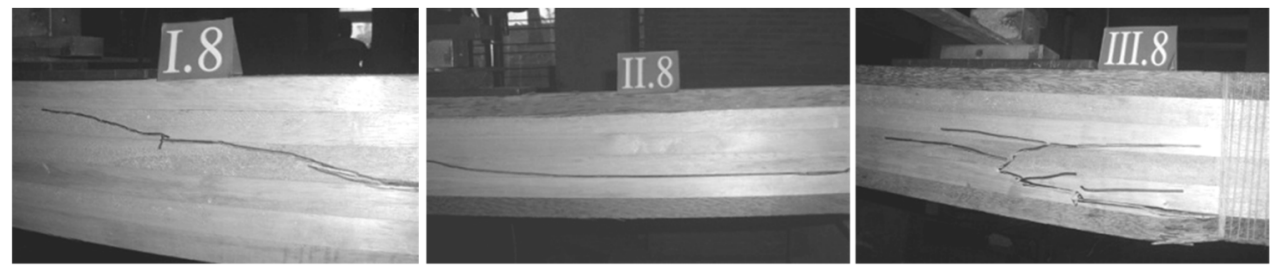

Fig. 11. Typical failure of glulam beams G8 Type I, II, III.

The shear failure occurred in all groups of beams with $\mathrm{L} / \mathrm{h}=8.2$. The shear failure was indicated by a horizontal crack propagation from the support area to the midspan of the beams. In this case, the use of nylon fiber reinforcement leads to changes in the mode of failure. The flexural failure of the beam was starting from the tension side that is not reinforced. So the application of nylon fiber reinforcement to glulam beams with $\mathrm{L} / \mathrm{d}=8.2$ caused the failure mode to change from shear mode to flexural mode.

\section{Conclusion}

The bending test results of glulam-beams shows differences in the elastic modulus, flexural strength and shear strength of the three types of glue-laminated timber beams. Placement of coconut wood as outer lamination and strengthening using nylon is very effective to increase the bending and shear capacity of glue-laminated timber beams. Based on the comparison of glulam beams consisting of six laminations (type I) of sengon wood it was found that the placement of the coconut wood as the outermost lamination succeeded in increasing the elastic modulus, the flexural and shear strength of beams by $28 \%, 13 \%$, and $34 \%$, respectively. In addition, the reinforcement with nylon straps results in an increase in the modulus of elasticity and shear strength of glulam by $41 \%$, and $49 \%$ respectively. In the case of bending strength, the reinforcement with nylon yarn is relatively unaffected.

\section{References}

1. R. N. J. Arancón, Asia-Pacific Forestry Sector Outlook Study: Focus on Coconut Wood. Working paper series: Asia-Pacific Forestry Towards 2010, Working Paper No. APFSOS/WP/23. Food and Agriculture Organisation of the United Nations, Rome, (1997)

2. ASTM D198-02., 2002. Standard Test Methods of Static Tests of Lumber in Structural Sizes, ASTM International, West Conshohocken, PA. 19428-2959, United States.

3. BPS, Statistics of Forestry Production 2014. Jakarta: Badan Pusat Statistik, (2015) 
4. G. Castro, F. Paganini, Mixed Glued Laminated Timber of Poplar and Eucalyptus Grandis Clones. European Journal of Wood and Wood Products, Volume 61 (4), pp. 291-298 (2003)

5. E. Fajriani, J. Ruelle, J. Dlouha, M. Fournier, Y. S. Hadi, W. Darmawan, Radial variation of wood properties of Sengon (Paraserianthes falcataria) and Jabon (Anthocephalus cadamba). Journal of the Indian Academy of Wood Science. Volume 10 (2), pp. 110-117, (2013)

6. L. Fathi, Structural and mechanical properties of the wood from coconut palms, oil palms, and date palms. Ph.D. Thesis. Fakultät für Mathematik, Informatik und Naturwissenschaften, Universität Hamburg, (2014)

7. S. Hay, K. Thiessen, D. Svecova, B. Bakht, The effectiveness of GFRP Sheets for Shear Strengthening of Timber. Journal of Composites for Construction, Volume 10 (6), pp. 483-491. (2006)

8. J. Jasienko, T. P. Nowak, Solid Timber Beams Strengthened with Steel Plates Experimental Studies. Construction and Building Materials, Volume 63, pp. 81-88. (2014)

9. L. A. Soltis, R. Douglas, Bending to Shear Ratio Approach for Beam Design. Forest Product Journal, Volume 47 (1), pp.104-108, (1997)

10. F. Taheri, G. P. Zou, M. Naghipour, Experimental and Theoretical Investigations into The Energy Absorption Response of GFRP-Strengthened Glulam Beams under Impact Loading. Forest Product Journal, Volume. 55 (4), pp.62-70, (2005) 